\title{
Время не ждет: экономическая политика как инструмент преодоления рецессии в России *
}

А.О. БАРАНОВ, доктор экономических наук, Новосибирский государственный университет, Институт экономики и организации промышленного производства СО РАН. E-mail: baranov@ieie.nsc.ru

В статье кратко анализируются итоги экономического развития России в 2015 г. Рассматриваются теоретические и практические вопросы применения инструментов фискальной и монетарной политики для преодоления рецессии в российской экономике.

Ключевые слова: рецессия в России, фискальная и монетарная политика

\section{Основные результаты развития экономики России в 2015 г.}

По данным Росстата, в 2015 г. ВВП России сократился относительно 2014 г. на 3,7\%, а индекс промышленного производства в целом - на 3,4\%, в том числе выпуск обрабатывающей промышленности - на 5,4\%, а в добывающей объем производства остался на уровне 2014 г. (темп роста составил 100,0\%) [1. С. 4, 7, 10].

Поквартальная динамика ВВП и валового выпуска промышленности в 2015 г. приведена на рисунке 1. Данные рисунка свидетельствуют о том, что в 3-4-м кварталах произошло небольшое снижение темпов падения ВВП и промышленного производства.

Инвестиции в основной капитал по сравнению с 2014 г. сократились на 8,7\%.

Негативные тенденции проявились и в динамике ряда других ключевых экономических показателей:

- усиление инфляции и отказ от индексации доходов бюджетников впервые за долгое время привели к существенному

* Работа выполнена при финансовой поддержке Министерства образования и науки России. 
уменьшению реальных располагаемых доходов населения (на 4\%) и реальной заработной платы (на 9,5\%);

- на 7,4\% возросла безработица;

- $\quad$ на $10 \%$ уменьшился оборот розничной торговли;

- на 2,1\% сократился объем платных услуг населению;

- примерно на 34,2\% упал внешнеторговый оборот, при этом импорт уменьшился существенно больше экспорта на $37,7 \%$ (экспорт - на 32,1\%).

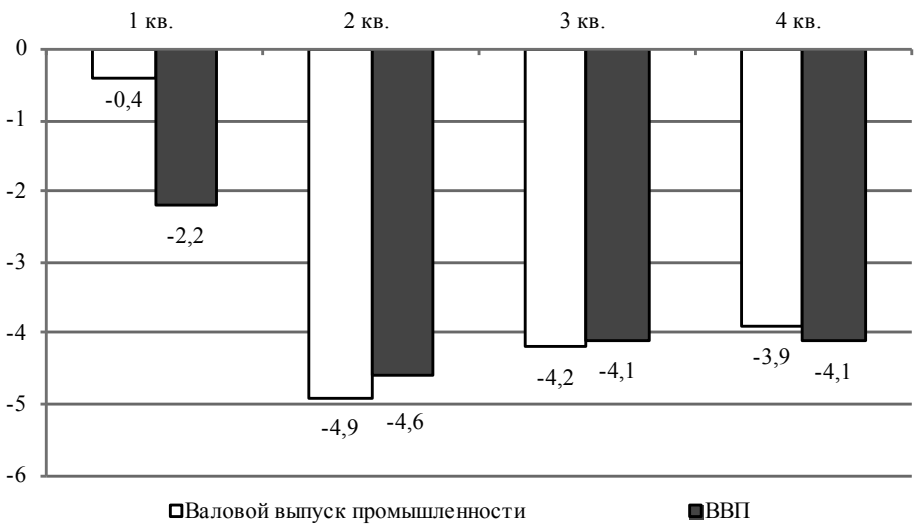

Источник: данные Росстата [2].

Рис. 1. Поквартальный темп прироста ВВП и валового выпуска промышленности в 2015 г.,\%

Таким образом, в 2015 г. в России имел место существенный экономический спад.

Значительная девальвация рубля в 2014-2015 гг. могла бы простимулировать импортозамещение. Этому же способствовал запрет на ввоз сельскохозяйственной продукции из США, Канады, стран ЕС и некоторых других.

Отметим, что импортозамещение в 2015 г. проявилось в основном лишь в пищевой промышленности. При этом в течение года по большинству позиций этот эффект имел затухающий характер. В 2015 г. относительно соответствующего периода 2014 г. производство мяса и мясопродуктов увеличилось на 5,0\% (+5,8\% в первом полугодии 2015 г.), переработанных и консервированных рыбо- и морепродуктов - на $0,3 \%(+5,0 \%)$, 
выпуск молочных продуктов вырос на 2,0\% (+3,0\%), кормов для животных - на 7,8\% (+7,5\% в первом полугодии 2015 г.) (табл. 1).

Таблица 1. Динамика производства отдельных видов пищевых продуктов в 2015 г., \%

\begin{tabular}{|l|c|c|c|}
\hline \multicolumn{1}{|c|}{ Показатель } & $\begin{array}{c}\text { I полугодие } \\
\mathbf{2 0 1 5} \text { г. } \\
\text { к I полугодию } \\
\mathbf{2 0 1 4} \text { г. }\end{array}$ & $\begin{array}{c}\mathbf{2 0 1 5} \text { г. } \\
\text { к 2014 г. }\end{array}$ & $\begin{array}{c}\text { Изменение } \\
\text { темпов при- } \\
\text { роста за весь } \\
\mathbf{2 0 1 5} \text { г. } \\
\text { к I полугодию, } \\
\mathbf{n . ~} \mathbf{~ . ~}\end{array}$ \\
\hline Производство мяса и мясопродуктов & 105,8 & 105,0 & $\mathbf{- 0 , 8}$ \\
\hline $\begin{array}{l}\text { Переработка и консервирование рыбо- и море- } \\
\text { продуктов }\end{array}$ & 105,0 & 100,3 & $\mathbf{- 4 , 7}$ \\
\hline $\begin{array}{l}\text { Переработка и консервирование картофеля, } \\
\text { фруктов и овощей }\end{array}$ & 102,7 & 98,4 & $\mathbf{- 4 , 3}$ \\
\hline $\begin{array}{l}\text { Производство растительных и животных масел } \\
\text { и жиров }\end{array}$ & 99,6 & 97,1 & $\mathbf{- 2 , 5}$ \\
\hline Производство молочных продуктов & 103,0 & 102,0 & $\mathbf{- 1 , 0}$ \\
\hline $\begin{array}{l}\text { Производство продуктов мукомольно-крупяной } \\
\text { промышленности, крахмалов и крахмалопродуктов }\end{array}$ & 102,3 & 102,2 & $\mathbf{- 0 , 1}$ \\
\hline Производство готовых кормов для животных & 107,5 & 107,8 & $+\mathbf{0 , 3}$ \\
\hline
\end{tabular}

Источник: [1. С. 14-16, 20-21], расчеты автора.

Помимо пищевой промышленности, позитивные тенденции, связанные с импортозамещением, имели место в химическом производстве, объем которого возрос в 2015 г. по сравнению с 2014 г. на 6,3\%, в том числе фармацевтической продукции на $8,9 \%$ [1. С. 26-29].

В остальных отраслях, особенно в машиностроении, возможный импортозамещающий рост производства сдерживался высокими процентными ставками на финансовом рынке и низким инвестиционным и потребительским спросом.

К положительным итогам года следует отнести прирост валового выпуска сельского хозяйства на 3\%. Необходимо отметить также сохранение положительного сальдо торгового баланса: 65,8 млрд долл. США [3] и увеличение прибыли в экономике примерно в 1,5 раза в номинальном выражении, или примерно на треть в реальном (за вычетом инфляции). Существенно сократился по сравнению с 2014 г. чистый вывоз капитала: co 153,0 млрд долл. в 2014 г. до 56,9 млрд долл. в 2015 г. При этом, в отличие от предыдущих лет, главной составляющей 
в структуре чистого вывоза капитала стало погашение частного внешнего долга.

Наиболее значимым было сокращение внешних обязательств банков, которое осуществлялось за счет не только продажи иностранных активов, но и средств, аккумулируемых по операциям текущего счета. Прочие секторы экономики, находясь в жестких условиях внешнего финансирования, также вынуждены были погашать внешнюю задолженность при минимальном за последние годы размере наращивания иностранных активов, главным образом, в форме прямых инвестиций.

Сальдированный финансовый результат (сумма прибылей минус сумма убытков) за январь-ноябрь 2015 г. составил 8337 млрд руб. Особенно значительно прибыль выросла в химическом производстве (в 15,5 раза!) и в финансовой деятельности (в основном это банки) - в 9,2 раза (!), в целлюлозно-бумажной промышленности - в 4,7 раза (!) [1. С. 88-90].

Рост прибыли производственных предприятий в условиях падающей экономики может быть объяснен только снижением издержек. Иначе говоря, производители активно сокращали расходы в условиях выживания в период кризиса. Рост прибыли создает потенциал для оживления инвестиционного процесса в 2016-2017 гг, так как возрастают финансовые возможности предприятий по самофинансированию инвестиций.

Что касается финансового сектора, то столь существенный рост прибыли был достигнут за счет огромного объема спекулятивных операций на валютном рынке, которые приносили, по оценке С. Ю. Глазьева, до 40\% годовых [4. С. 25]!

\section{Состояние бюджета}

По предварительным данным Минфина РФ, исполнение основных показателей консолидированного бюджета (сумма федерального бюджета и бюджетов субъектов Федерации) за 2015 г. составило [5]:

- объем поступивших доходов - 26474,7 млрд руб.;

- исполнение расходов - 29338,9 млрд руб.;

- дефицит - (-) 2864,2 млрд руб., или примерно 3,6\% ВВП России за 2015 г.

Необходимо отметить, что в связи со снижением доходов бюджета из-за падения производства в 2015 г. для финансирования 
дефицита федерального бюджета использовались средства Резервного фонда РФ в размере примерно 1,3 трлн руб. (рис. 2).

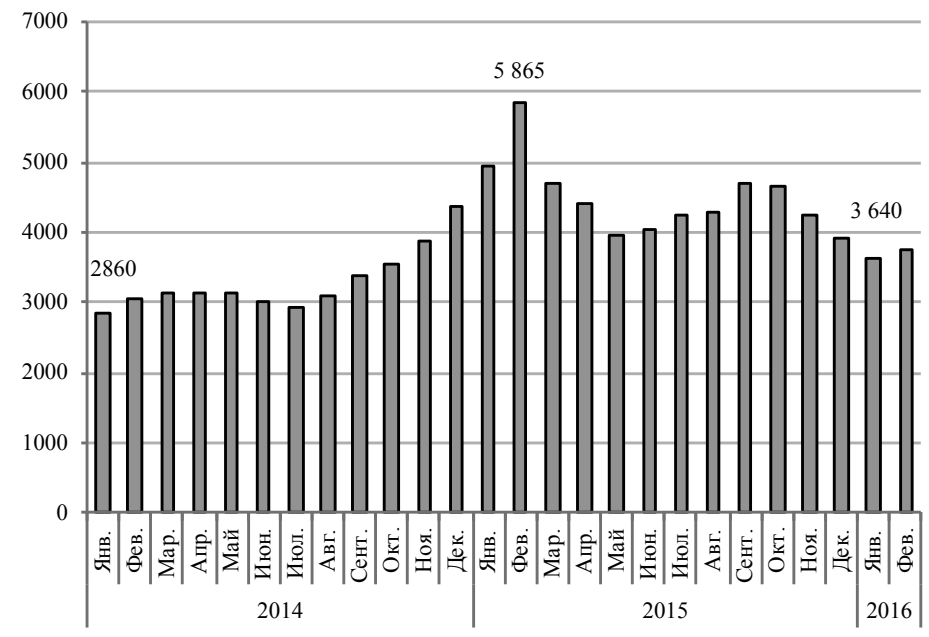

Источник: данные Минфина РФ [5].

Рис. 2. Динамика Резервного фонда России в 2014-2016 гг. (на 1-е число месяца), млрд руб.

Помимо этого, в феврале-марте 2015 г. в соответствии с постановлениями Правительства Российской Федерации средства Фонда национального благосостояния были размещены в ценные бумаги, связанные с реализацией инфраструктурных проектов, предусмотренных Перечнем самоокупаемых инфраструктурных проектов, реализуемых юридическими лицами, в финансовые активы которых размещаются средства Фонда национального благосостояния и (или) пенсионных накоплений, находящихся в доверительном управлении государственной управляющей компании, на возвратной основе (утвержден распоряжением Правительства РФ от 05.11.2013 г. № 2044-р). Средства были направлены на строительство Центральной кольцевой автомобильной дороги, а также модернизацию Байкало-Амурской и Транссибирской железнодорожных магистралей.

По состоянию на 1 февраля 2016 г. совокупный объем средств Резервного фонда и Фонда национального благосостояния составлял примерно 9,8 трлн руб., или около 12\% ВВП. Наличие 
этих фондов по-прежнему является гарантией финансовой стабильности экономики России.

\section{Экономическая политика как инструмент преодоления кризиса 2015-2016 гг.}

Возвращаясь к итогам 2015 г., нельзя не отметить, что наиболее негативный результат - падение реальных доходов населения - проявится и в 2016 г. Законом № 371-ФЗ Правительство России заморозило до 2017 г. заработные платы гражданским и военным государственным служащим и пенсии работающим пенсионерам [6]. Принятие этого закона особенно несправедливо по отношению к работающим пенсионерам, многие из которых потому и работают, что на пенсию прожить очень сложно (средняя пенсия в конце 2015 г. - 12900 руб. в месяц). Удивительно, но Правительство РФ решило сэкономить во время кризиса на самых незащищенных слоях населения!

В связи с этим вновь в острой форме встает вопрос о том, какой набор инструментов кредитно-денежной и фискальной политики может быть использован для возвращения к экономическому росту.

\section{Кредитно-денежная политика}

Краткий экскурс в теорию вопроса.

Центральный банк России в последние годы перешел к так называемому инфляционному таргетированию, т. е. достижению целей по инфляции. Это решение, а главное, методы его реализации вызвали серьезную дискуссию среди экономистов - практиков и теоретиков. В связи с этим считаем целесообразным остановиться на некоторых теоретических вопросах регулирования инфляции с целью перевода острой дискуссии по этому вопросу из русла эмоций в сферу здравого макроэкономического анализа.

На инфляцию влияет целый ряд факторов. В известной модели динамического совокупного спроса - динамического совокупного предложения (DAD-SAS) $[7,8]$, используемой для анализа инфляции многими исследователями, отражено влияние на инфляцию многочисленных факторов, основные из которых следующие:

1) инфляционные ожидания, которые формируются под воздействием инфляции предыдущих периодов, изменения курса 
национальной валюты, ожиданий относительно смены экономической политики правительства и некоторых других факторов;

2) так называемый разрыв (разница) между потенциальным и реальным ВВП. При этом под потенциальным ВВП понимается его значение при естественном (устойчивом) уровне безработицы. Если ВВП страны выше потенциального, то имеет место очень высокая занятость, растут заработные платы и увеличивается инфляция (важным вопросом является оценка естественного уровня безработицы);

3) темп роста номинальной денежной массы. Считается, что при его увеличении, при прочих равных условиях, инфляция возрастает, а при сокращении - падает;

4) рост государственных расходов - в краткосрочном плане он может оживить производство и инфляцию;

5) изменение поведения населения в потреблении и сбережении, которое учитывается в так называемом коэффициенте предельной склонности к потреблению, показывающем максимальный рост потребления при увеличении ВВП на единицу;

6) величина налоговых ставок;

7) прирост реального ВВП и значения ВВП в предыдущем периоде;

8) чувствительность инвестиций к изменению ВВП и ставки процента;

9) общая величина реального предложения денег, то есть денежной массы с учетом влияния на нее общего уровня цен;

10) изменение заработной платы и более широко - величины доходов населения;

11) тарифы естественных монополий, влияющие на общий уровень цен, и некоторые другие факторы.

Приведенный перечень заставляет любого здравомыслящего человека (необязательно профессионального экономиста или финансиста) задуматься о том, что уменьшением предложения денег (снижением номинальной и реальной величины денег в экономике) можно не добиться уменьшения инфляции, поскольку другие факторы могут оказать более значительное воздействие на цены в противоположном направлении, и инфляция только усилится.

Проведенный нами статистический анализ факторов, влияющих на инфляцию в экономике России в постсоветский период, показывает, что вариация инструментов монетарной политики, включая изменение денежной массы, является важным 
фактором, который воздействует на динамику цен, но определяет ее лишь на 20-25\% [9].

Особо обратим внимание на седьмой фактор воздействия на инфляцию - прирост реального ВВП. В теоретическом уравнении динамического совокупного спроса он включается со знаком минус, чему есть строгое математическое доказательство. То есть при увеличении производства возрастает количество товаров и услуг, противостоящих денежной массе, и это приводит к снижению цен. Почему? В связи с усилением предложения товаров и услуг на рынке возрастает конкуренция, и это способствует снижению цен в ходе конкурентной борьбы за рынок. Интересно, что в результате многочисленных расчетов с использованием методов математической статистики по оценке факторов, влияющих на инфляцию в России, этот отрицательный знак статистически всегда подтверждается [9].

Из этого следует важный вывод: применяя политику уменьшения денежной массы в экономике, приводящую к высоким процентным ставкам, денежно-кредитные власти стремятся сократить инфляцию, но в реальности падение производства уменьшает предложение товаров и услуг вследствие сокращения кредитования и может усугубить рост цен.

Действительно, поддержание высоких процентных ставок в экономике уменьшает склонность компаний и домашних хозяйств к использованию кредита. Это, в свою очередь, снижает совокупный спрос на товары длительного пользования и производственного назначения, на жилье. В рыночной экономике уменьшение спроса приводит к снижению производства. Отрицательный прирост ВВП, как показывают расчеты по экономике России, стимулирует инфляцию.

Конечно, отрицательный разрыв ВВП относительно его потенциального значения (второй фактор среди перечисленных выше) приводит к сокращению заработной платы и действует в направлении уменьшения инфляции. Однако, подчеркнем это еще раз, другие проинфляционные факторы могут перекрыть действие данного рычага. При этом рост безработицы вследствие падения производства может иметь тяжелые социальнополитические последствия.

В условиях нынешней экономической ситуации в России (падение цен на нефть, санкции Запада) очень важен также другой фактор стимулирования инфляции - рост инфляционных 
ожиданий вследствие значительной (более чем вдвое за два года) девальвации рубля. Отметим также, что, кроме стимулирования инфляционных ожиданий, девальвация национальной валюты прямо поддерживает инфляцию через увеличение цен импортных товаров.

Сочетание падения производства вследствие чрезмерно жесткой монетарной политики с резким уменьшением цен на основной экспортный товар - нефть, западными санкциями и ростом инфляционных ожиданий может привести к отрицательному резонансному эффекту внутри экономической системы России. Накладывающиеся друг на друга перечисленные факторы усугубляют падение производства и инфляцию - экономика оказывается в ситуации так называемой стагфляции - когда усилению инфляции сопутствует падение производства.

Увеличение количества денег в экономике (монетарную экспансию) обычно рассматривают как фактор ее краткосрочного оживления. По нашему мнению, необходим более широкий взгляд на этот инструмент регулирования экономического роста. Увеличение предложения денег ведет к уменьшению процентных ставок. Низкие процентные ставки стимулируют рост инвестиций в основной капитал, что приводит к ускорению темпов его обновления и прироста, являющемуся важнейшим фактором, определяющим экономическую динамику в среднесрочном u долгосрочном планах. В этом смысле кредитно-денежная политика становится инструментом не только оперативного регулирования экономической динамики, но и важнейшим мостом, соединяющим краткосрочное оживление экономики с ее долгосрочным ростом.

Реализация кредитно-денежной политики Банка России в 2014-2016 z2.

К сожалению, в России в 2015 г. имела место стагфляция: ВВП снизился на 3,7\%, а инфляция усилилась с 11,4\% в 2014 г. до 12,9\% в 2015 г. В соответствии с прогнозом международных аналитических центров, падение производства в России в 2016 г. продолжится [10]. По нашему прогнозу, спад ВВП в России в 2016 г. составит не менее $2 \%$.

Несмотря на критику со стороны многих экономистов и финансистов, Центральный банк России продолжает проводить жесткую кредитно-денежную политику. По нашей оценке, 
за два года - с четвертого квартала 2013 г. по четвертый квартал 2015 г. - реальное среднеквартальное предложение денег (денежный агрегат M2) в экономике России сократилось примерно на $10 \%$ (рис. 3). Вслед за уменьшением денежного предложения и ростом ставок на рынке межбанковского кредитования пошли вверх проценты по кредитам для физических и, особенно, для юридических лиц. Сжатие реальной денежной массы и высокие процентные ставки, мягко говоря, не содействуют выходу экономики России из кризиса.

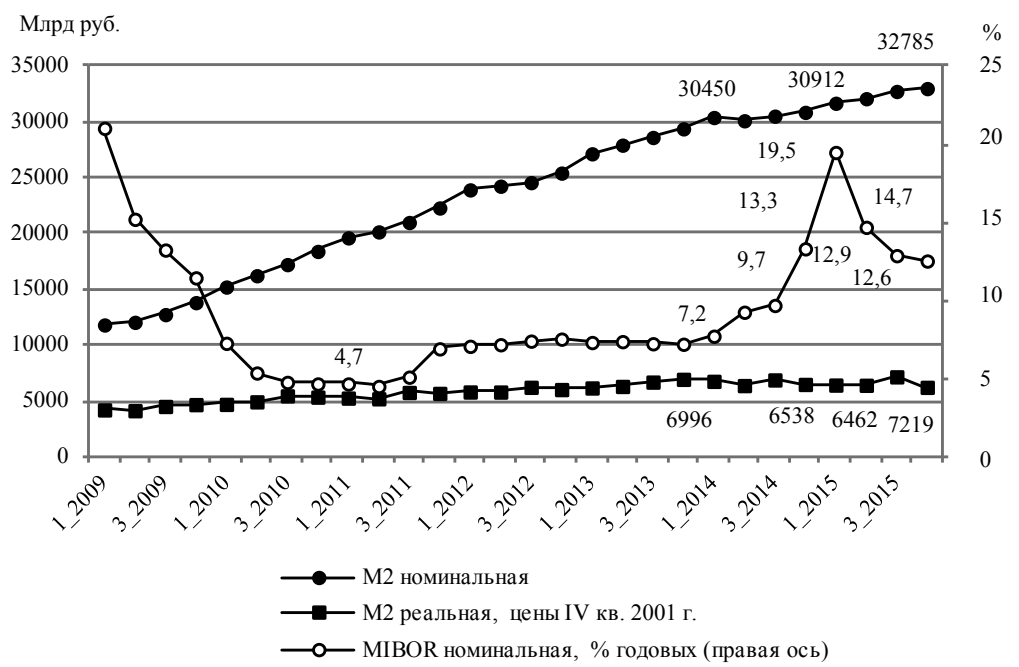

Источник: [2], расчеты автора.

Рис. 3. Поквартальная динамика денежной массы и нормы процента в России в 2009-2015 гг., млрд руб.

В течение 2015 г. под давлением экспертного сообщества, ряда членов Правительства РФ и Государственной думы Банк России снизил ключевую ставку с 17\% до 11\% годовых. В результате в 2015 г. проценты на межбанковском рынке несколько уменьшились (см. рис. 3). При этом и номинальные, и реальные ставки рынка межбанковского кредитования попрежнему существенно превышают их значение в 2013-2014 гг. По нашей оценке, среднеквартальная реальная ставка² на рынке

\footnotetext{
${ }^{2}$ В упрощенном виде реальная ставка процента определяется как разность между номинальной ставкой процента и инфляцией.
} 
межбанковского кредитования в первом квартале 2014 г. была равна примерно 1,0\% годовых, а в четвертом квартале 2015 г. $6,8 \%$ годовых (почти в семь раз выше!).

Мы по-прежнему не разделяем энтузиазма официальных властей России относительно кредитно-денежной политики, проводимой Банком России. В качестве основной цели Банк России провозгласил снижение инфляции до 4\% в 2017 г. и дальнейшее ее поддержание вблизи указанного уровня [11]. При этом с 10 ноября 2014 г. Центральный банк РФ принял решение о переходе к плавающему курсу рубля, не исключив, правда, своих интервенций на валютном рынке [12]. Время для перехода к плавающему курсу было выбрано крайне неудачное в условиях западных санкций против России и снижения цен на основные экспортные товары, ограничивших приток валюты в страну. Дальнейший ход событий, завершившийся паникой на валютной бирже и обвалом рубля в середине декабря 2014 г., подтвердил несвоевременность принятого Центральным банком России решения об отмене бивалютного коридора.

Обвал обменного курса рубля резко усилил инфляционные ожидания и сделал более дорогим импорт, что существенно обесценило все усилия по предотвращению ускорения инфляции в России.

Подведем итоги деятельности Банка России с учетом результатов 2015 г. $^{3}$

Итог первый: потребительская инфляция усилилась с 6,5\% в 2013 г. до $11,4 \%$ в 2014 г. и $12,9 \%$ в 2015 г.

Итог второй: золотовалютные резервы России снизились с 509,6 млрд долл. на 1 января 2014 г. до 379 млрд долл. на 1 января 2015 г. и 368,4 млрд долл. на 1 января 2016 г. Тезис о том, что «мы не будем палить наши золотовалютные резервы», не подтвердился, а валютный рынок в России был раскачан в результате некомпетентных действий Банка России, простимулировав инфляционные ожидания, которые воздействовали в направлении усиления инфляции и перекрыли все усилия по антиинфляционному регулированию путем уменьшения предложения денег.

Итог третий: темп роста ВВП экономики России стал отрицательным.

\footnotetext{
${ }^{3}$ Критика монетарной политики Банка России давалась автором ранее в работе [13].
} 
Несомненно, на экономический рост негативно повлияли санкции Запада против России, неблагоприятный для предпринимательства климат в стране, резкое уменьшение цен на нефть. Однако санкции и падение цен на нефть начали действовать со второй половины 2014 г. и не могли оказать немедленного воздействия на экономическую динамику. По нашему мнению, «санкции» Банка России, которые он начал осуществлять с начала 2014 г., внесли не менее значительный вклад в остановку экономического роста в России, и можно сказать с полной уверенностью, что проводимая в 2014-2015 гг. кредитно-денежная политика никак не содействовала оживлению экономики.

Банк России через жесткую кредитно-денежную политику и обесценение рубля негативно влияет на экономический рост по трем направлениям: 1) увеличение процентных ставок (рис. 4) затрудняет кредитование инвестиционных проектов, ипотечное кредитование, приобретение в кредит товаров длительного пользования населением, что снижает инвестиционный и потребительский спрос; 2) из бюджета выделяются миллиарды рублей на субсидирование процентных ставок и на поддержание ликвидности банковской системы, что усугубляет проблему его дефицита; 3) обесценение рубля удорожает импортные сырье и оборудование.

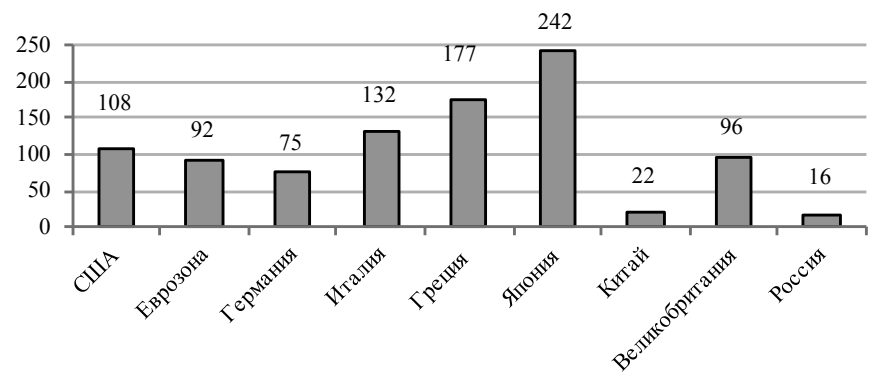

Источники: [14-16], расчеты автора.

Рис. 4. Отношение государственного долга к ВВП в различных странах в 2014-2015 гг.,\%

Последнее самым негативным образом сказывается на переоснащении новым оборудованием отраслей национальной экономики. Импорт обеспечивает подавляющую часть новых машин и оборудования, вводимых в действие в экономике 
России (в 2014 г. объем импорта машин и оборудования 156 млрд долл.) [17. С. 518]. Обесценение рубля в 2014-2015 гг. более чем вдвое негативно отразилось на инвестициях в активную часть основного капитала, существенно удорожая их цену в рублях, хотя, конечно, позитивно повлияет (и это уже происходит) на доходы бюджета в рублях.

Отметим, что к изменению монетарной политики давно и настойчиво призывает целый ряд видных экономистов России, включая советника Президента России по экономике академика С. Ю. Глазьева [4]. Этой же точки зрения придерживаются известный российский бизнесмен и уполномоченный при Президенте РФ по защите прав предпринимателей Б. Ю. Титов [18], а также участники «Столыпинского клуба» [19].

В связи с этим остается открытым вопрос, почему с упорством, достойным иного применения, Центральный банк России продолжает проводить губительную для экономического роста монетарную политику? Почему не принимается во внимание альтернативная точка зрения, состоящая в необходимости немедленного перехода к контролируемому монетарному стимулированию экономического роста?

Обращаясь к зарубежному опыту, необходимо сказать, что ФРС США формулирует свои цели намного шире и прагматичней, чем ЦБ РФ, включая в их число достижение максимальной занятости [20]. Федеральная резервная система США, Банк Японии, Банк Англии в период после 2007 г. неоднократно прибегали (и прибегают) к практике значительного расширения денежной массы и снижения процентных ставок. В США и в Англии эти меры дали положительный эффект - экономический рост возобновился, а занятость существенно повысилась.

\section{Фискальное стимулирование выхода из рецессии}

Фискальные инструменты стимулирования экономического роста давно известны в теории и практике экономической политики: снижение налогов, рост государственных расходов, увеличение трансфертов.

Что касается трансфертов, то Правительство России приняло решение об их снижении в реальном исчислении, так как пенсии в 2016 г. будут проиндексированы частично, а работающим пенсионерам не будут индексироваться вообще. Наряду с отказом от индексации заработной платы бюджетникам это приведет 
к существенному уменьшению совокупного спроса на потребительские товары и отнюдь не будет содействовать оживлению производства.

Относительно налоговых ставок принято решение не трогать большую их часть в 2016 г. Исключением являются увеличивающиеся акцизы на бензин и дизельное топливо, табак и алкоголь. Акцизы на бензин и дизельное топливо решено повысить дважды на 2 руб. за литр: с 1 января и с 1 апреля 2016 г.

Может ли Россия позволить себе в условиях бюджетного дефицита использовать другой классический инструмент фискального стимулирования - наращивать государственные расходы? Для ответа на этот вопрос обратимся к статистике российского государственного долга.

За период после 2008 г. отношение суммарного (внутреннего плюс внешнего) государственного долга к ВВП возросло с 6\% до $13 \%$. С учетом долга субъектов РФ и муниципальных образований в 2015 г. отношение государственного долга к ВВП составляло $16 \%$ (табл. 2).

Таблица 2. ВВП и государственный долг России в 2008-2015 гг.

\begin{tabular}{|l|c|c|c|c|c|c|}
\hline \multicolumn{1}{|c|}{ Показатель } & $\mathbf{2 0 0 8}$ & $\mathbf{2 0 0 9}$ & $\mathbf{2 0 1 0}$ & $\mathbf{2 0 1 1}$ & $\mathbf{2 0 1 3}$ & $\mathbf{2 0 1 5}$ \\
\hline ВВП, млрд руб. & 41276,8 & 38807 & 46309 & 55967 & 66755,3 & 80413 \\
\hline Государственный долг - всего, млрд руб. & 2302 & 3498 & 4155 & 5243 & 7503 & 10229 \\
\hline внутренний долг, млрд руб. (на конец года) & 1500 & 2095 & 2940 & 4191 & 5722,2 & 7160 \\
\hline внешний долг, млрд долл. (на конец года) & 32 & 44 & 40 & 36 & 55,8 & 50,1 \\
\hline внешний долг, млрд руб. & 802 & 1403 & 1215 & 1052 & 1780,4 & 3068,8 \\
\hline Отношение госдолга к ВВП, \% & 6 & 9 & 9 & 9 & 11 & 13 \\
\hline В том числе: & & & & & & \\
\hline Внутренний госдолг, \% & 4 & 5 & 6 & 7 & 9 & 9 \\
\hline Внешний госдолг, \% & 2 & 4 & 3 & 2 & 3 & 4 \\
\hline Внешний долг, всего (на конец года), млрд долл. & 480 & 467 & 476 & 545,4 & 714 & 538,2 \\
\hline Внешний долг, всего (на конец года), млрд руб. & 11918 & 14880 & 14444 & 16032 & 22787 & 32967 \\
\hline Отношение всего внешнего долга к ВВП, \% & 29 & 38 & 31 & 29 & 34 & 41 \\
\hline $\begin{array}{l}\text { Справочно: объем госдолга субъектов РФ } \\
\text { и муниципальных образований, млрд руб. }\end{array}$ & & & 1158 & 1387 & 1741 & 2659,9 \\
\hline $\begin{array}{l}\text { Отношение госдолга к ВВП с учетом долга субъектов РФ } \\
\text { и муниципальных образований, \% }\end{array}$ & & & 11 & 12 & 14 & 16 \\
\hline
\end{tabular}

Источники: данные Минфина РФ [5] и Центрального банка России [2], расчеты автора.

Вместе с тем отношение государственного долга к ВВП в России остается одним из самых лучших в мире. В США этот 
показатель составляет 108\%, в Еврозоне - 92\%, в Японии - 242\%, в Германии $-75 \%$ (рис. 4).

Правда, если принять во внимание весь российский внешний долг, включающий долги банков и предприятий, то картина менее радужная - отношение его к ВВП в 2015 г. составляло $41 \%$ (см. табл. 2). Однако аналогичный прием применительно к экономикам других стран также привел бы к намного более печальным для этих стран статистическим результатам. Кроме того, необходимо помнить, что государство не несет обязательств по долгам фирм.

Примем за основу нашего укрупненного расчета ВВП экономики России в 2015 г., равный 80,4 млрд руб. При постепенном наращивании отношения государственного долга к ВВП до уровня Китая (22\%), т. е. на 6\%, например, в течение трех лет, государство может вложить в развитие экономики 3,2 трлн руб., или более 1 трлн руб. ежегодно. При этом не возникает никакой существенной опасности с точки зрения обслуживания государственного долга. Даже если предположить, что весь дефицит федерального государственного бюджета 2016 г., планируемый в размере 3\% от ВВП [21], будет покрыт за счет эмиссии государственных облигаций, отношение госдолга к ВВП в России составит $25 \%$, что является вполне приемлемым показателем.

В реальности отношение госдолга к ВВП может быть меньше, так как вследствие монетарного и фискального стимулирования ВВП России начнет расти в 2017-2018 гг.

Аналитические расчеты с использованием динамической межотраслевой модели экономики России показывают, что мультипликаторы государственных расходов ${ }^{4}$ для валового выпуска экономики в целом имеют наибольшее значение для следующих направлений государственных расходов: на приобретение продукции строительства - 2,4, машиностроения - 2,4, услуг здравоохранения - 2,3 и образования - 2,2 [22]. Если дополнительные государственные расходы будут направлены в виде инвестиций на реализацию инфраструктурных или инновационных проектов, то их материально-вещественным наполнением будет в основном продукция строительства и машиностроения.

${ }^{4}$ Мультипликатор, или множитель, показывает, насколько возрастет валовой выпуск или ВВП при увеличении государственных расходов на единицу. 
В результате суммарный дополнительный прирост валового выпуска экономики России в 2016-2018 гг. может составить около 7,7 трлн руб. (3,2 трлн руб. х 2,4= 7,7 трлн руб.), а ВВП - примерно 4,3 трлн руб., так как доля ВВП в валовом выпуске в российской экономике в 2014 г. составила 56,6\% [23. С. 22]. Следовательно, рост государственных расходов на реализацию инвестиционных проектов даст дополнительный прирост ВВП в 2016-2018 гг. в среднем в год более 1,4 трлн руб. (4,3 трлн руб./3 = 1,4 трлн руб.), или примерно $1,8 \%$ от уровня ВВП России в 2015 г. Такой дополнительный прирост ВВП стал бы существенным вкладом в преодоление рецессии.

Очевидно, что рост государственных расходов не должен осуществляться в виде «раздачи денег». Средства должны выделяться целевым образом под конкретные проработанные инвестиционные проекты. Должен быть реализован механизм контроля за использованием выделенных государственных финансовых ресурсов, что не в полной мере удалось сделать во время кризиса 2009 г.

Какие расходы планирует правительство в антикризисном плане на 2016 г.?

Прежде всего, обращает на себя внимание незначительный объем средств, выделенных на его реализацию, -880 млрд руб. (примерно 1\% ВВП), в том числе дополнительные средства, не включенные ранее в бюджетные расходы, - 210 млрд руб. (примерно 0,3\% ВВП) $)^{5}$.

Четыре отрасли получат антикризисную поддержку в приоритетном порядке: автомобилестроение, транспортное машиностроение, жилищное строительство и легкая промышленность. Например, 38,8 млрд руб. на 2016 г. зарезервированы в рамках антикризисных мер Правительства РФ для поддержки спроса на автомобили (включает в себя программы утилизации, tradein, льготного лизинга и льготного автокредитования). Субсидии на компенсацию затрат по инвестиционным кредитам составят 7,2 млрд руб.

Другие направления - поддержка регионов, субсидирование ипотечных кредитов, меры по ускоренному списанию вагонов

\footnotetext{
${ }^{5}$ На момент написания статьи антикризисный план Правительства России еще не был утвержден и не опубликован, поэтому автор пользовался данными из СМИ ([24-25]).
} 
с истекшим сроком службы и обновлению парка грузового подвижного состава и т. д.

\section{Выводы}

Краткий анализ мер, предпринимаемых Правительством России и Центральным банком России по преодолению рецессии, позволяет сделать следующие выводы.

Банк России по-прежнему проводит жесткую монетарную политику под предлогом борьбы с инфляцией. Фактически же высокие процентные ставки негативно влияют на потребительский и инвестиционный спрос и, в конечном итоге, тормозят возрождение производства. Высокая волатильность обменного курса рубля, наблюдаемая с конца 2014 г., является важнейшим фактором, повышающим неопределенность в экономике России, что в конечном итоге также становится препятствием для перехода к положительным темпам роста.

Перечень фискальных антикризисных мер Правительства РФ показывает, что они носят характер «затыкания дыр». Нет стратегических решений, которые могли бы возродить экономический рост. Доминирует совершенно необоснованная боязнь увеличения госдолга.

Фактически Правительство России и Центральный банк РФ (отдают они себе в этом отчет или нет) своим пассивным поведением в области реализации мер экономической политики по переходу к положительным темпам роста в основном уповают на «невидимую руку рынка», которая обеспечит экономике возрождение. Такая политика в условиях явных и неявных (снижение цен на нефть) экономических санкций со стороны Запада представляется по меньшей мере наивной. История знает немало примеров печальных последствий такой пассивности и ошибок органов управления экономикой, самым ярким из которых является Великая депрессия в США в 1929-1933 гг.

Даже если российская экономика при отсутствии энергичных мер стимулирующего характера «сама вытащит себя за волосы» из кризиса, как барон Мюнхгаузен, нас ожидают годы депрессии или вялого экономического роста со всеми вытекающими негативными последствиями. Рано или поздно придется сделать выбор в пользу активного использования методов монетарного и фискального стимулирования. Однако время может быть потеряно! 
Хотелось бы поддержать высказанную академиком А. Г. Аганбегяном на страницах журнала «ЭКО» идею о более активном общении руководителей страны с экспертами-экономистами [26. С. 6]. Круг лиц, которые могли бы реально донести свое мнение до руководства страны по вопросам экономического развития России, должен быть значительно расширен. Общение с экспертным сообществом должно носить регулярный характер, как это практикуется в США. Иначе возникает опасность совершения стратегических ошибок на основе учета мнения только узкого круга лиц.

\section{Литература}

1. Информация о социально-экономическом положении России. 2015 год (предварительные данные). - М.: Росстат, 2015.

2. Сайт Росстата: URL: http://www.gks.ru/wps/wcm/connect/rosstat_main/ rosstat/ru/statistics/accounts/\# (дата обращения: 29.01.2016).

3. Сайт Центрального банка России: URL: http://www.cbr.ru/statistics/? Prtld=svs (дата обращения: 03.02.2016).

4. Глазьев С. Ю. О неотложных мерах по укреплению экономической безопасности России и выводу российской экономики на траекторию опережающего развития. - М.: Институт экономических стратегий, Русский биографический институт, 2015.

5. Сайт Минфина PФ URL: http://www.minfin.ru/ru/document/\# (дата обращения: 04.02.2016).

6. Федеральный закон от 14.12.2015 № 371-Ф3 «О внесении изменений в Федеральный закон “О приостановлении действия положений отдельных законодательных актов Российской Федерации в части порядка индексации окладов денежного содержания государственных гражданских служащих, военнослужащих и приравненных к ним лиц, должностных окладов судей, выплат, пособий и компенсаций и признании утратившим силу Федерального закона "О приостановлении действия части 11 статьи 50 Федерального закона "О государственной гражданской службе Российской Федерации" в связи с Федеральным законом "О федеральном бюджете на 2015 год и на плановый период 2016 и 2017 годов“». URL: http://publication.pravo. gov.ru/Document/View/0001201512150017 (дата обращения: 06.02.2016).

7. Dornbusch R., Fischer S., Startz R. Macroeconomics.12th Edition. McGrawHill, 2014.

8. Blanchard O. Macroeconomics. Third Edition. Upper Saddle River. - N. J.: Prentice Hall, 2003.

9. Баранов А. О., Сомова И. А. Анализ основных факторов инфляционной динамики в России в постсоветский период // Проблемы прогнозирования. - 2015. - № 2. - С. 16-32.

10. Доклад МВФ «Перспективы развития мировой экономики». 19 января 2016 г. URL: http://www.imf.org/external/Russian/pubs/ft/survey/so/2015/ NEW070915AR.htm (дата обращения: 22.01.2016). 
11. Основные направления единой государственной денежно-кредитной политики на 2016 год и период 2017 и 2018 годов. URL: http://www.cbr.ru/ publ/ondkp/on_2016\%282017-2018\%29.pdf (дата обращения: 27.01.2016). 12. Политика валютного курса Банка России. URL: http://www.cbr.ru/DKP/? Prtld=e-r_policy (дата обращения: 02.02.2016).

13. Баранов А.О. Оценка глубины и длительности рецессии в России и меры Правительства РФ по ее преодолению // ЭКО. - 2015. - № 4. C. $72-92$.

14. URL: http://en.wikipedia.org/wiki/List_of_sovereign_states_by_public_debt (дата обращения: 25.01.2016).

15. URL: http://www.usgovernmentspending.com/federal_debt_chart.html (дата обращения: 20.02.2016).

16. URL: http://epp.eurostat.ec.europa.eu/statistics_explained/index.php/ Government_finances_statistics (дата обращения: 25.02.2016), расчеты авторов.

17. Россия в цифрах. 2015. - М.: Росстат, 2015.

18. Борис Титов призвал «Единую Россию» принять программу перевода экономики на новые рельсы. URL: http://ombudsmanbiz.ru/2016/02/boristitov-prizval-edinuyu-rossiyu-prinyat-programmu-perevoda-ekonomiki-nanovye-relsy/ (дата обращения: 06.02.2016).

19. Советник Путина предложил запустить печатный станок. URL: http:// www.rbc.ru/economics/21/10/2015/56264d4f9a79470f39f19d2a (дата обращения: 20.02.2016).

20. Statement on Long-Run Goals and Monetary Policy Strategy. URL: http:// www.federalreserve.gov/monetarypolicy/files/FOMC_LongerRunGoals.pdf (дата обращения: 15.01.2016).

21. Ключ от закона, где деньги лежат // Российская газета. -16 дек. - 2015. URL: http://www.rg.ru/2015/12/17/fbudjet.html (дата обращения: 25.02.2016). 22. Baranov A., Krashenina $K$. Experiment of the calculation of government spending multipliers for Russian economy using the dynamic input-output model [Electronic resource] // The twenty-third Inforum World Conference. Bangkok, Thailand. August 23th to August 29th, 2015 / Chulalongkorn University. - Bangkok, 2015. - Mode of access. URL: http://inforumweb.umd.edu/papers/conferences/2015/russia_baranov_2015_slides.pdf (дата обращения: 25.01.2016). 23. Национальные счета России в 2007-2014 гг.: Стат. сб. - М., 2015.

24. Антикризисный план 2016 - меньше средств, больше действий. URL: http://tass.ru/ekonomika/2626307 (дата обращения: 01.02.2016).

25. Минэкономразвития внесло в правительство доработанный план поддержки экономики. URL: http://tass.ru/ekonomika/2697560 (дата обращения: 27.02.2016).

26. Аганбегян А. Г. Как преодолеть стагнацию и восстановить экономическое развитие // ЭКО. - 2016. - № 2 (500). - С. 3-10. 